\title{
GRUPO DE ESTUDOS SOBRE A PROTEÇÃO INTERNACIONAL DE MINORIAS DA FACULDADE DE DIREITO DA UNIVERSIDADE DE SÃO PAULO - GEPIM/USP
}

\author{
GROUP OF STUDIES ON INTERNATIONAL PROTECTION OF MINORITIES FACULTY OF LAW OF \\ THE UNIVERSITY OF SÃO PAULO - GEPIM/USP
}

Paulo Borba Casella* Felipe Nicolau Pimentel Alamino**

O Grupo de Estudos sobre a Proteção Internacional de Minorias da Faculdade de Direito da Universidade de São Paulo - GEPIM/USP é um grupo de pesquisa que tem como objeto a realização de estudos, pesquisas, reuniões, eventos e trabalhos sobre a proteção de minorias no Direito Internacional, enfocando prioritariamente temas jurídicos, mas também propondo discussões multidisciplinares.

Historicamente, minoria em Direito Internacional compreende minorias religiosas, minorias étnicas, minorias linguísticas e, atualmente, minorias de orientação sexual e identidade de gênero, que se convenciona chamar de grupo LGBT+. Todavia, o GEPIM explora também a pesquisa relativa à proteção internacional dos povos indígenas, os quais, ainda que não sejam considerados de maneira técnica como 'minorias', compartilham muitas das necessidades de proteção.

A presente coletânea reúne uma série de estudos elaborados com foco na proteção de minorias, a partir de casos correspondentes aos vários subnúcleos destas, assim como relativos à proteção dos direitos dos povos indígenas.

$\mathrm{O}$ artigo sobre o caso Kokkinakis vs. Grécia, o primeiro caso sobre liberdade religiosa perante a Corte Europeia de Direitos Humanos - CEDH versa sobre a condição de um cidadão grego, Testemunha de Jeová, em um país de maioria cristã ortodoxa, sendo considerado delito por proselitismo religioso.

A seguir, o artigo sobre o Genocídio Armênio no Direito Internacional, analisa o conceito de genocídio cunhado pelo jurista Raphael Lemkin dentro do contexto histórico do massacre de uma minoria étnica, os armênios, dentro do Império Otomano durante a Primeira Guerra Mundial. Da mesma forma, o artigo sobre o caso Bagdonavicius e Outros vs. Rússia, na CEDH, trata da demolição de casas na Rússia e da retirada forçada de membros da minoria roma destas casas, também chamados de ciganos, grupo que também sofreu perseguições ao longo da história, sobretudo na Segunda Guerra Mundial.

\footnotetext{
* Professor Titular de Direito Internacional Público da Faculdade de Direito da Universidade de São Paulo.

** Mestrando em Direito Internacional Público na Faculdade de Direito da Universidade de São Paulo.
} 
O caso Sejdić e Finci contra a Bósnia e Herzegovina, também da Corte Europeia, trata da importante participação política, em estado democrático, de minorias étnicas, mesmo considerando-se o frágil equilíbrio político no país.

A seguir, os artigos sobre os Princípios de Yogyakarta e sobre o caso Christine Goodwin vs. Reino Unido tratam da temática LGBT+ dentro do contexto de proteção a minorias. O primeiro analisa os documentos intitulados Princípios de Yogyakarta e Princípios de Yogyakarta +10 , que vêm para reiterar a necessidade da proteção de direitos fundamentais aos grupos LGBT+, além de fazer breve levantamento do número de países que ainda criminalizam as condutas de pessoas destes grupos. Por sua vez, o artigo sobre o caso Christine Goodwin discorre sobre os esforços de uma cidadã britânica trans em ter seus direitos reconhecidos pelo governo do Reino Unido, relativos à previdência social e a preservação de sua intimidade.

Depois desta série de artigos sobre minorias específicas, ou seja, étnicas, religiosas e LGBT+, passamos a dois artigos que abordam minorias em contexto geral, o primeiro com análises sobre o relatório da ONU sobre a missão da Relatora Especial para questões de minorias no Brasil, documentando os avanços ocorridos no país nos últimos anos, sem deixar de apontar as violações ainda existentes e merecedoras de cuidados, enquanto o segundo, intitulado Proteção das Minorias no Direito Internacional, faz levantamento histórico da proteção de minorias, até o momento da adoção dos Princípios de Yogyakarta, dando panorama atual dos últimos desenvolvimentos na área, inclusive em seus reflexos práticos no Brasil.

Por fim, fecha este bloco de artigos o trabalho sobre o caso Norín Catrimán e Outros (dirigentes, membros e ativista do povo indígena Mapuche) vs. Chile relativo à proteção internacional dos povos indígenas, tema que, embora não seja especificamente relativo a minorias e sim a povos indígenas, faz necessária análise, primeiramente para diferenciar estes dois conceitos e, também para trazer luz, ao que pode ser compartilhado em matéria de proteção. 